\title{
Free phenolic compounds extraction from Brazilian halophytes, soybean and rice bran by ultrasound-assisted and orbital shaker methods
}

\author{
MANUEL M. DE SOUZA ${ }^{1}$, BIBIANA DA SILVA ${ }^{2}$, CÉSAR S.B. COSTA ${ }^{1}$ and ELIANA BADIALE-FURLONG ${ }^{2}$ \\ ${ }^{1}$ Laboratório de Biotecnologia de Halófitas/BTH, Instituto de Oceanografia/IO, Universidade \\ Federal do Rio Grande/FURG, Av. Itália Km 8, 96203-900 Rio Grande, RS, Brazil \\ ${ }^{2}$ Programa de Pós-Graduação em Engenharia e Ciência de Alimentos, Universidade Federal do Rio Grande/FURG, Laboratório de \\ Micotoxinas e Ciência de Alimentos, Escola de Química e Alimentos/EQA, Av. Itália Km 8, 96203-900 Rio Grande, RS, Brazil
}

Manuscript received on September 21, 2017; accepted for publication on January 29, 2018

\begin{abstract}
In several countries halophytes are commercially cultivated in low saline or even irrigated with seawater, as well as with saline aquaculture effluent, like a sea asparagus Sarcocornia ambigua, that show a biotechnological potential for bioactive compounds production. However, their recovery from matrix is sometimes inefficient because the lignocellulosic materials difficult the solvent action when drastic conditions are not applied. The ultrasound-assisted extraction (UAE) was optimized by a central composite rotational design for recovery free phenolic compounds (FPC) from the sea asparagus S. ambigua. Optimum conditions were validated and compared with orbital shaker extraction for $S$. ambigua, other Brazilian halophytes (Apium graveolens, Myrsine parvifolia, Paspalum vaginatum, and Schinus terebinthifolius), soybean and rice bran. Except for P. vaginatum, soybean and rice bran, UAE yielded 18-29\% higher FPC than that of the orbital shaker. Besides this analytical performance UAE method optimized is faster than the orbital shaker, providing shorter exposure of the analyst to the extractor solvent and applicable in matrices with different compositions. It was also demonstrated that halophytes species showed to be good natural sources of FPC in a better way as soybean and rice bran. This work was the first to report FPC in M. parvifolia and P. vaginatum.
\end{abstract}

Key words: sea asparagus, celery, Brazilian pepper, sea water crops.

\section{INTRODUCTION}

Phenolic compounds are synthesized by several plants and they play a structural role, working on signalling and defense, and against oxidative damage (Garcia-Salas et al. 2010). For humans, the control of free radicals by phenolic compounds from vegetable sources can have positive effects

Correspondence to: Manuel Macedo de Souza

E-mail:mcsouza@furg.br on health, including control of different types of cancer (Stanković et al. 2015).

High contents of phenolic compounds are found in coastal halophytes (salt tolerant plants), which produce these compounds in order to survive under stressful conditions (high salt concentration, periodical submersion, frequently high levels of soil contaminants; Costa et al. 2006, Rozema and Schat 2013, Flowers and Colmer 2015, Mishra et al. 2015). Their phenolic contents are directly 
proportional to the intensity of environmental stress during growth (Costa et al. 2006, Ventura et al. 2011, Bertin et al. 2014) and several of these compounds produced by halophytes have bioactive properties, detected in vitro and in vivo (e.g. antibacterial, and antiviral) (Stanković et al. 2015, Wang et al. 2016).

In several countries some halophytes are commercially cultivated in low saline or even irrigated with seawater, as well as with saline aquaculture effluent (e.g. Amaranthaceae as Salicornia and Sarcocornia species), for seed oil production, animal food and human diet (Glenn et al. 2013, Rozema and Schat 2013, Costa et al. 2014). There are few studies on the amount of phenolic compounds, as well as on the composition and/or content of individual phenolic acids and flavonoids in commercial halophytes (Bertin et al. 2014, Wang et al. 2016). Due to the rapid increase on the demand for natural bioactive substances, there is a need for further phytochemical and pharmacological characterization of halophytes by an efficient procedure with a good recovery and few damages to chemical compounds structure (Stanković et al. 2015).

There are several methods for phenolic compounds extraction. Among the most frequently reported method is the extraction by orbital shaker (Scaglioni et al. 2014, Schmidt et al. 2014). However, the high amount of sample mass, type (e.g. methanol) and the large solvent volume required make this extraction method slow, dangerous and expensive. Ultrasound-assisted extractions (UAE) are mainly based on microstreaming and sonochemical effects. In general, are employed baths and probe-type systems UAE. Probe can deliver a higher ultrasonic power than ultrasonication bath (up to 100 times more), and is considered a more effective technique (Santos et al. 2009). Typically, ultrasonication bath present power and wave frequency fixed (Wang et al. 2016), which could limit the technique performance. Thus
UAE with probe system can help to fill the gap of knowledge on halophytes' phenolic compounds constitution, intended to identify new sources of functional vegetables to animal and human diet.

Native halophytes in Brazil show good biomass production in their habitats and represent a biotechnological potential for bioactive compounds production, such as phenolic compounds, which has not yet been adequately explored. The perennial sea asparagus Sarcocornia ambigua (Michx.) M.A.Alonso \& M.B.Crespo has been introduced as a new halophytic crop under irrigation with saline water and shrimp farm effluents in different climatic regions in Brazil (Costa et al. 2014, Bertin et al. 2016, Costa and Herrera 2016). Fresh and dry $S$. ambigua shoots have high nutritional quality for animal (Costa et al. 2014) and human diets (Bertin et al. 2014, Timm et al. 2015), being well accepted by Brazilians as pickle in vinegar (Timm et al. 2015). Bertin et al. (2014) have found a high phenolic acid and flavonoids content in $S$. ambigua shoots, using an orbital shaker extraction and determination by HPLC-ESI-MS/MS. Some of the compounds found in alcoholic extracts of $S$. ambigua (chlorogenic acids and quercetin, for example) seem to be responsible for high antioxidant and free radical scavenger activity.

In this work, UAE was optimized by a central composite rotational design for recovery of free phenolic compounds (FPC) from sea asparagus Sarcocornia ambigua. Additionally, optimum conditions were validated and compared with orbital shaker extraction for S. ambigua, other Brazilian halophytes (Apium graveolens, Myrsine parvifolia, Paspalum vaginatum, and Schinus terebinthifolius), soybean and rice bran.

\section{MATERIALS AND METHODS}

\section{SAMPLES}

All experiments for the UAE optimization were accomplished with cylindrical leafless shoots of 
S. ambigua. The 100 days old S. ambigua were harvested at ground level from a $90 \mathrm{~m}^{2}$ cultivated plot in the city of Aracati (northeast Brazilian state of Ceará; 04 33' S). Plants were spaced $25 \mathrm{~cm}$ apart and watered by filling up drainage ditches once a day, with $1350 \mathrm{~L}$ of saline effluent $\left(40 \mathrm{~g} \mathrm{NaCl} \mathrm{L}^{-1}\right)$ from a Litopenaeus vannamei shrimp tank. Only apical branches with fertile segments (with seeds) were utilized. After harvesting, the samples were freeze dried $\left(-50{ }^{\circ} \mathrm{C} ; 72 \mathrm{~h}\right)$.

The optimized UAE procedure was applied in others halophytes with detected bioactivity. Celery Apium graveolens L. (antioxidant), seashore paspalum Paspalum vaginatum $\mathrm{Sw}$. (rich in free radical scavengers), and the deciduous marsh trees Myrsine parvifolia A. DC. (antibacterial) and Schinus terenbithifolius Raddi (antioxidant and antimicrobial) (Suffredini et al. 2006, Yao et al. 2010, Uddin et al. 2012, Uliana et al. 2016), as well as soybeans and rice bran.

Seeds of $A$. graveolens were collected in the Pólvora Island salt marsh located in Rio Grande (RS, Brazil; 32 $2^{\circ} 01^{\prime} \mathrm{S}, 52^{\circ} 06^{\prime} \mathrm{W}$ ). Vegetative propagules of $P$. vaginatum were from active germplasm bank of the Laboratório de Biotecnologia de Halófitas (BTH; Instituto de Oceanografia, FURG, Rio Grande, RS, Brazil); accession 2006/010-Caravelas. Plants of these two halophytes were cultivated in commercial organic compost irrigated with freshwater for two months in the greenhouse of BTH before harvest. Fully-expanded green leaves of M. parvifolia and $S$. terebinthifolius were collected in the Carreiros Campus of FURG, in Rio Grande $\left(32^{\circ} 04^{\prime} \mathrm{S}\right.$, $\left.52^{\circ} 09^{\prime} \mathrm{W}\right)$. Soybeans and rice bran matrices were provided by the Brazilian Agricultural Research Corporation (EMBRAPA, Londrina, PR, Brazil) and purchased at a local shop (Rio Grande, RS, Brazil), respectively. All above cited samples were dried in oven $\left(60^{\circ} \mathrm{C} ; 48 \mathrm{~h}\right)$, grinded in a knives mill, sieved through $0.50 \mathrm{~mm}$, and maintained in freezer at $-20^{\circ} \mathrm{C}$, until determinations were obtained.

\section{REAGENT AND ANALYTICAL SOLUTIONS}

All solutions were prepared from analytical reagent grade chemicals ( $>95$ per cent of purity). Ethanol, zinc sulfate, barium hydroxide, sodium carbonate and copper sulphate were provided by Synth (Brazil). Sodium potassium tartrate was provided by Vetec (Sigma-Aldrich, Brazil) and FolinCiocalteu phenol reagent $(2 \mathrm{~N})$ from Dynamics (Brazil)

\section{EXPERIMENTAL DESIGN FOR UAE OPTIMIZATION}

The central composite rotational design (CCRD) was applied to optimize UAE of FPC from $S$. ambigua. CCRD $2^{2}$ was used, with 11 trials (Table I), including three replicates at the center point. The effect of extraction time $(1,9,30,51$, and $60 \mathrm{~min})$ and power of ultrasonic waves $(100,150,275,400$, and $450 \mathrm{~W}$ ) variables were investigated. Samples $(250 \mathrm{mg})$ with addition of $15 \mathrm{~mL}$ of ethanol 80 per cent were submitted to extraction in focused ultrasound (Ultrasonic disruptor Ecosonics, Ultronique, QR500, $60 \mathrm{~Hz}, 20 \mathrm{kHz}, 500 \mathrm{~W}$, Brazil). Then, each extract was clarified with $2.50 \mathrm{~mL}$ of barium hydroxide $0.1 \mathrm{M}$ and $2.5 \mathrm{~mL}$ of zinc sulfate 5 per cent, centrifuged (Centrifuge Eppendorf $5804 \mathrm{R}$, Germany) at $2990 \mathrm{x} \mathrm{g}$ and filtrated for analysis. The final volume was $25 \mathrm{~mL}$. Ethanol is a widely used solvent for extraction of polar FPC (Krishnaswamy et al. 2013, Wang et al. 2016) and the levels of variables studied in this experimental design were chosen based on preliminary tests (data not shown).

Acoustic intensity was determined for the optimal conditions using following formula (González-Centeno et al. 2015):

$$
\begin{aligned}
& I=\frac{P}{\pi r^{2}} \\
& P=m C_{p} \frac{\Delta T}{t}
\end{aligned}
$$


where "I" is the acoustic intensity $\left(\mathrm{W} / \mathrm{cm}^{2}\right)$, "P" is the ultrasonic power applied (W), " $\mathrm{r}$ " is the radius of the probe $(0.2 \mathrm{~cm})$, " $\mathrm{m}$ " is the mass of solvent $\left(12.510^{-3} \mathrm{~kg}\right)$, " $\mathrm{C}_{\mathrm{p}}$ " is the specific heat capacity of the solvent $\left(4180 \mathrm{~J} \mathrm{~kg}^{-1} \mathrm{~K}^{-1}\right)$, " $\mathrm{T}$ " is the temperature $(\mathrm{K})$, and " $\mathrm{t}$ " is the sonication time (s).

\section{Validation of the proposed optimized UAE method}

The parameters assessed for validation were limit of detection (LD) and limit quantification (LQ) repeatability and accuracy. $\mathrm{LD}$ and $\mathrm{LQ}$ were estimated in 0.14 and $0.45 \mu \mathrm{g} \mathrm{mL}^{-1}$, respectively. Limit of detection was estimated by three times standard deviation of blanks divided by the angular coefficient, and limit of quantification by five times standard deviation divided by the angular coefficient (AOAC 2002).

Accuracy was obtained in triplicate and measured by the percentage of recovery of fortified $S$. ambigua shoot samples, with three levels of a standard of gallic acid (intermediate values of the standard curve of gallic acid), in amounts of 416, 520 and $728 \mu \mathrm{g} \mathrm{g}^{-1}$ of the sample (dry weight), by equation 1 . For complete evaporation of the solvent, solutions of the three amounts of gallic acid diluted in methanol were prepared and placed on the samples to be analyzed 24 hours before analysis. Samples with methanol and without gallic acid were prepared simultaneously as control. The repeatability was tested by the precision on the assays performed to recovery, on the same day, by assessing the relative standard deviation (\%RSD) of the results obtained.

Extraction recovery $(\%)=\frac{\text { calculated concentration of gallic acid }}{\text { experimental concentration of gallic acid }} \times 100$

\section{EXTRACTION BY ORBITAL SHAKER}

Samples $(250 \mathrm{mg})$ with addition of $10 \mathrm{~mL}$ of ethanol 80 per cent were submitted to extraction in an orbital shaker (Tecnal TE-420, Brazil) at $180 \mathrm{rpm}$, for $60 \mathrm{~min}$, at $25.0^{\circ} \mathrm{C}$. Then, agitation was stopped for $15 \mathrm{~min}, 5 \mathrm{~mL}$ of ethanol 80 per cent was added and agitation started again for $90 \mathrm{~min}$. Extracts were clarified with $2.5 \mathrm{~mL}$ of barium hydroxide 0.1 $\mathrm{M}$ and $2.5 \mathrm{~mL}$ of zinc sulfate 5 per cent, centrifuged at $2990 \mathrm{x} g$ and filtrated for posterior analysis. The final volume was $25 \mathrm{~mL}$.

\section{QUANTIFICATION OF FPC}

Free phenolic compounds were measured by the Folin-Ciocalteu method, using a spectrophotometer (Biospectro, SP-22, Brazil) (Souza et al. 2009). Extracts $(0.5 \mathrm{~mL})$, distilled water $(0.5 \mathrm{~mL})$ and alkaline solution $(4.5 \mathrm{~mL})$ of sodium carbonate, copper sulphate and sodium potassium tartrate (100:1:1) were placed into a bath at $40^{\circ} \mathrm{C}$ for 15 min. The Folin-Ciocalteu (1:2) was added $(0.5 \mathrm{~mL})$ and after 10 min the absorbance was measured at $750 \mathrm{~nm}$. The concentration of FPC was estimated from a standard curve of gallic acid (concentration ranging from 1.7 to $8.6 \mu \mathrm{g} \mathrm{mL}^{-1}$ ) and expressed as milligram of gallic acid equivalents (GAE) per gram of dry weight sample (mg GAE $\mathrm{g}^{-1} \mathrm{dw}$ ). Measurements were performed in triplicate.

\section{STATISTICAL ANALYSIS}

All determinations were carried out in triplicate and the results obtained were expressed as means and standard deviation. The optimal extraction conditions of FPC from S. ambigua were set through the construction of a quadratic polynomial model. The multiple regression model was built on the actual data of FPC response to extraction time, power ultrasound and their interaction, considering both linear and quadratic fitting. The regression model fitting was assessed by Analysis of Variance (ANOVA) and Fisher F-test at 95 per cent confidence interval. Student's " $t$ " tests were applied to investigate the statistical significance of regression coefficients. Surface plots were employed to visualize to relationship between FPC response and experimental factors. 
Student's t-test was applied to compare difference in FPC recover between UAE and shaker extractions methods for each vegetable matrix $(p<$ $0.05)$.

\section{RESULTS AND DISCUSSION}

UAE OPTIMIZATION FOR PHENOLIC EXTRACTION FROM S. ambigua SHOOTS

The Folin-Ciocalteu method is one the most utilized for quantification of free phenolic compounds (e.g. Arruda et al. 2017). Only between the years 2016 and 2017 were published more than nine thousand papers using this method for FPC determination. Although the Folin-Ciocalteu reagent is nonspecific for phenolic compounds, this reaction is favored by medium alkaline (Singleton and Rossi 1965).

Concentrations of FPC in $S$. ambigua shoots ranged between 16.3 and $20.0 \mathrm{mg} \mathrm{GAE} \mathrm{g}^{-1} \mathrm{dw}$ in CCRD $2^{2}$ (Table I). The multiple regression showed that power ultrasound (linear and quadratic term) and extraction time (quadratic term) significantly affected FPC extraction by UAE $(p<0.05$ ) (see Table IIa). The power ultrasound was the factor with the highest influence (small $p$ value of the quadratic term) in FPC concentration, with higher concentrations observed at intermediate potency levels $(275 \mathrm{~W})$ (Table I). Extraction time at 30 min produced high FPC values from $S$. ambigua shoots and longer extractions led to slightly lower contents, and the interaction between tested factors had no significant effect (Table IIa). Wang et al. (2016) also found lower extractions of gallic acid under ultrasonic exposure for more than $50 \mathrm{~min}$ and suggested that longer ultrasonic exposure could lead to degradation of extracts (by rise in temperature) and/or lower recoveries associated with slow diffusion (increased of the solvent viscosity by evaporation).

The optimized mathematical model relating extraction time $(\mathrm{T})$ and ultrasound power $(\mathrm{P})$ with the content of FPC in terms of significant independent factors was (equation 2):

$\mathrm{Y}_{\mathrm{FPC}}=19.9-0.49 \mathrm{~T}^{2}+0.81 \mathrm{P}-1.29 \mathrm{P}^{2}$

The relation between observed and predicted values pointed out a strong positive correlation $\left(\mathrm{R}^{2}=0.93\right.$; see Table IIb) and the regression results showed that the model is significant $(\mathrm{F}$-value $=29.89, p<$ 0.001; Table IIb) and can be used to predict FPC content from S. ambigua shoots obtained by UAE.

The response surface (Figure 1) as well as raw data (Table I) show higher FPC content in central point's tested. Through the first partial assessment, the $Y_{\mathrm{FPC}}$ equation detected the optimum values of 30 min and $315 \mathrm{~W}$, for extraction time and ultrasound power, respectively (integer values were utilized because of the machine settings). The optimal conditions found in the intermediated parameters values generate a maximum temperature during the 30 min sonication time of $55.0^{\circ} \mathrm{C}\left(328.15^{\circ} \mathrm{K}\right)$ and a consequent acoustic intensity (I) of $5.89 \mathrm{~W}$ $\mathrm{cm}^{-2}$. Acoustic/ultrasound intensity is proportional to the amplitude of ultrasound (and ultrasonic power applied is proportional the amplitude). In

TABLE I

Central composite rotational design and results for the extraction of free phenolic compounds (FPC) from Sarcocornia ambigua shoot biomass.

\begin{tabular}{|c|c|c|c|}
\hline Trials & $\begin{array}{l}\text { Extraction } \\
\text { time (min) }\end{array}$ & Power (W) & $\begin{array}{c}\text { FPC } \\
\left(\mathrm{mg} \mathrm{GAE} \mathrm{g^{-1 }} \mathrm{dw}\right)\end{array}$ \\
\hline 1 & $9(-1)$ & $150(-1)$ & 17.0 \\
\hline 2 & $51(+1)$ & $150(-1)$ & 17.7 \\
\hline 3 & $9(-1)$ & $400(+1)$ & 19.5 \\
\hline 4 & $51(+1)$ & $400(+1)$ & 19.3 \\
\hline 5 & $1(-1,41)$ & $275(0)$ & 18.7 \\
\hline 6 & $60(+1,41)$ & $275(0)$ & 18.6 \\
\hline 7 & $30(0)$ & $100(-1,41)$ & 16.3 \\
\hline 8 & $30(0)$ & $450(+1,41)$ & 17.9 \\
\hline 9 & $30(0)$ & $275(0)$ & 20.0 \\
\hline 10 & $30(0)$ & $275(0)$ & 19.9 \\
\hline 11 & $30(0)$ & $275(0)$ & 19.8 \\
\hline
\end{tabular}

$\mathrm{dw}$ - dry weight; GAE - Galic acid equivalent. 
TABLE II

Multiple regression coefficients and analysis of variance

(ANOVA) of the effects of extraction time (T; min)

and ultrasound power $(\mathrm{P} ; \mathrm{W})$ on the extraction of free

phenolic compounds (FPC; mg GAE $\mathrm{g}^{-1}$ dry-weight) from $S$. ambigua shoot biomass.

(a) Coefficients

\begin{tabular}{ccccc}
\hline Variable & Coefficient & SE & t-value & $p$-value \\
\hline Constant & 19.90 & 0.25 & 78.90 & $<0.0001$ \\
T (L) & 0.05 & 0.31 & 0.29 & 0.7815 \\
T (Q) & -0.49 & 0.37 & -2.67 & 0.0445 \\
P (L) & 0.81 & 0.31 & 5.52 & 0.0034 \\
P (Q) & -1.29 & 0.37 & -6.99 & 0.0009 \\
T (L) x P (L) & -0.21 & 0.44 & -0.94 & 0.3881
\end{tabular}

(b) ANOVA

\begin{tabular}{cccccc}
\hline Source & SS & $d f$ & MS & F-value & $p$ value \\
\hline Model & 14.6 & 3 & 4.88 & 29.9 & 0.0002 \\
Error & 1.14 & 7 & 0.16 & &
\end{tabular}

$\mathrm{R}^{2}$

0.93

L - Linear; Q - Quadratic; SE - Standard error of coefficient; SS - Sum of Square; $d f$ - degree of freedon; MS - Mean Square.

low acoustic intensity, are not observed cavitation. Cavitation bubbles are created by ultrasound cross of the medium. When collapsing bubbles are generating zones of high pressure and temperature, occur extraction process. However, elevated acoustic intensity (or power) can lead to rapid deterioration of the compounds (Santos et al. 2009). Under these optimal conditions of extraction, the experimental values detected FPC concentration in $S$. ambigua shoots were $24.4 \pm 4.21 \mathrm{mg} \mathrm{GAE} \mathrm{g}^{-1} \mathrm{dw}$. Considering the value predicted by equation 2 ; this FPC concentration detected presents a coefficient of variation of 17.7 per cent.

\section{Validation of the proposed method}

The accuracy was evaluated by the mean of recovery percentages of gallic acid (equation 1) from the fortified S. ambigua samples by the optimized UAE method. According to AOAC (2002), the recovery

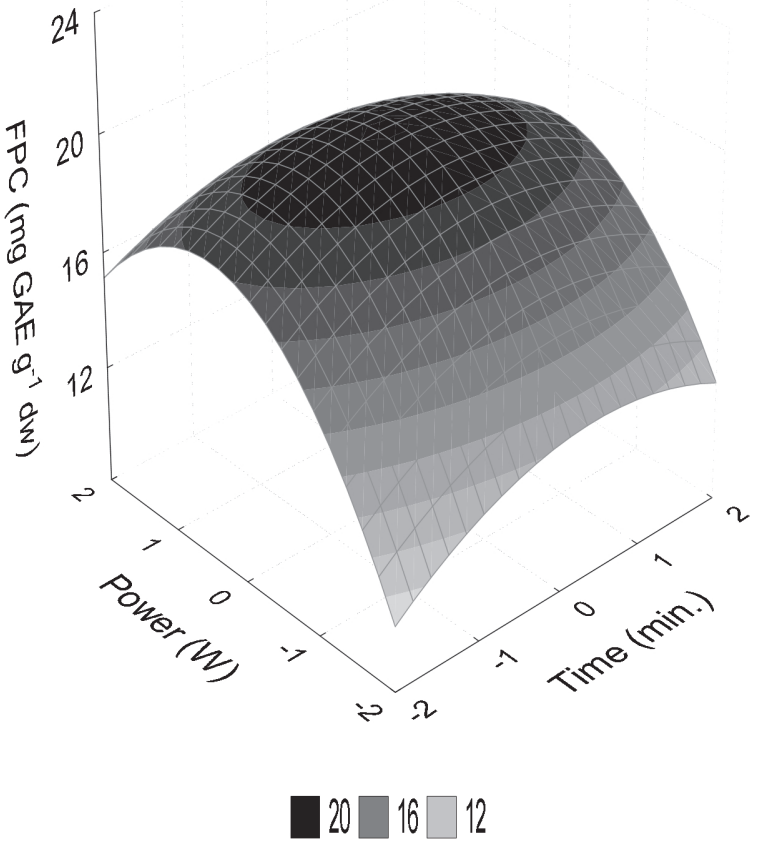

Figure 1 - Surface response plot (3D) presenting the effects of extraction time (min) and ultrasound power (W) on the extraction of free phenolic compounds (FPC; mg GAE g ${ }^{-1}$ dryweight) from Sarcocornia ambigua shoot biomass.

limits acceptable are a function of the concentration and the purpose of the analysis. For the three levels studied $\left(416,520\right.$ and $\left.728 \mu \mathrm{g} \mathrm{g}^{-1} \mathrm{dw}\right)$, the recovery percentages were 101, 97.4 and 100 per cent respectively, which means that the method presents the expected accuracy, approximately 99.5 per cent. Precision was calculated by the coefficient of variation $(\mathrm{CV})$ of the three replicates of each level tested. The CVs of 416, 520 and $728 \mu \mathrm{g}$ gallic acid $\mathrm{g}^{-1} \mathrm{dw}$ were $2.8,10$, and 8.0 per cent, respectively, showing that the precision of this method is acceptable $(<15$ per cent) (AOAC 2002).

\section{EXTRACTION METHODS AND PHENOLIC COMPOUNDS RECOVERY}

The UAE with optimized parameters to $S$. ambigua shoots was applied in other halophyte matrices, soybeans and rice bran to obtain FPC contents, and these values were compared with the orbital shaker extraction (Figure 2). Except for P. vaginatum shoots, on average, the UAE method yielded 


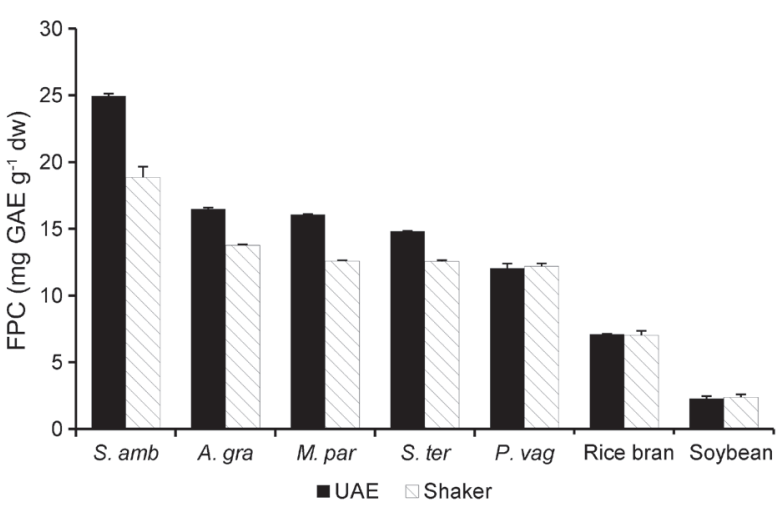

Figure 2 - Average values ( \pm standard-deviation) of free phenolic compounds (FPC) concentration (mg GAE g ${ }^{-1}$ dryweight) from different matrices obtained by two extraction methods; UAE - Ultrasound-assisted extraction; Shaker orbital shaker. ${ }^{*} p<0.01 ; * * p<0.001$. S. amb - Sarcocornia ambigua; A. gra - Apium graveolens; M. par - Myrsine parvifolia; S. ter - Schinus terebinthifolius; P. vag - Paspalum vaginatum.

significantly higher amounts of FPC, 18 - 29 per cent, than the shaker method for all halophytes studied. Halophytes have, to a larger or lesser degree, convergent physiological and anatomicmorphological adaptations to salt stress, such as high lignification of their tissues and ions, and organic osmolites accumulation in their cells (Jbir et al. 2001, Flowers and Colmer 2015, Lutts and Lefèvre 2015, Slama et al. 2015). These characteristics are partially responsible for the form in which the phenols associate with halophyte matrices (i.e. free and bound phenols). Our results suggest that halophytes possess interfering compounds and/ or are rich in more bound phenols, which passive processes of FPC extraction (dependent on the solvent capacity of penetration into the cell), such as orbital shaker, have difficulty to access and extract from the plant sample. The active process of UAE is more efficient for matrices with more bound phenols concentrations, since the cavitation produced in the solvent by the focused ultrasonic waves (and consequently high temperature and pressure) allowed extraction of greater contents of phenolic compounds (Garcia-Salas et al. 2010).
Higher UAE efficiency in halophyte matrices may also be associated with the reduced analytical time exposure to the solvent effect, and consequent reduced time of more labile phenolic compounds exposure to oxidative degradation. Higher recovery of ultrasound-assisted extractions of numerous bioactive compounds, such as phenols, than traditional methods (e.g. orbital shaker) have been previously reported (Abid et al. 2014, Wang et al. 2016). Our results show that the utilization of $\mathrm{UAE}$ is an important asset to a proper evaluation of the halophytes potential as a source of FPC and probably of other bioactive compounds. Further studies are necessary in order to clarify why UAE improves phenols extraction from halophytes.

Among the matrices analyzed, halophyte plants presented the higher contents of phenolic compounds. The highest FPC yield for $S$. ambigua shoots $\left(25.0 \pm 0.17 \mathrm{mg} \mathrm{GAE} \mathrm{g}^{-1} \mathrm{dw}\right)$ was obtained with UAE method, whereas shaker extraction yielded $18.8 \pm 0.81 \mathrm{mg} \mathrm{GAE} \mathrm{g}^{-1} \mathrm{dw}$. Moreover, FPC concentrations found were greater than blackberry, red raspberry, strawberry, blueberry, cherry (De Souza et al. 2014), grape seeds (Krishnaswamy et al. 2013), and even others halophytes (Crithmum maritimum L. and Inula crithmoïdes L.; Jallali et al. 2014). Many previous works have shown the phenolic extraction potential and the main phenolic compounds of Sarcocornia species (Ventura et al. 2011, Bertin et al. 2014, Stanković et al. 2015).

In this work it was detected an average FPC concentration of $16.5 \pm 0.09 \mathrm{mg} \mathrm{GAE} \mathrm{g}^{-1} \mathrm{dw}$ for Apium graveolens shoots by UAE (Shaker $=13.8$ $\pm 0.07 \mathrm{mg} \mathrm{GAE} \mathrm{g}^{-1} \mathrm{dw}$ ), a halophyte widely used in human food and a member of the Apiaceae family, like coriander, parsley and anise. This content of a marsh originated accession was 10-folds higher than values found by Yao et al. (2010) in commercial celery cultivars (averages ranging from 1.12-1.74 mg GAE g ${ }^{-1}$ for $A$. graveolens).

Both the Brazilian pepper S. terebinthifolius (Wheeler et al. 2001) and M. parvifolia (Ribeiro 
and Costa 2015) are widely spread trees in Brazil, occurring in the inland border of coastal wetlands and also in drier habitats of coastal plains. Brazilian pepper seeds are traditionally used as condiment and its leaves are utilized in folk medicine for numerous health treatments (e.g. respiratory problems and rheumatism) (Uliana et al. 2016). Though our study disclosed a high FPC average content in leaves of $S$. terebinthifolius $(\mathrm{UAE}=$ $14.8 \pm 0.02 \mathrm{mg} \mathrm{GAE} \mathrm{g}^{-1} \mathrm{dw}$; Shaker $=12.5 \pm 0.10$ mg GAE $\mathrm{g}^{-1} \mathrm{dw}$ ), Uliana et al. (2016) founded a much higher value in leaves (221.63 mg GAE $\mathrm{g}^{-1} \mathrm{dw}$ ). This difference may be associated to the extraction method employed, since Uliana et al. (2016) utilized high leaf mass ( $60 \mathrm{~g}$ ) and volume of solvent $(400 \mathrm{~mL})$ and longer extraction time (seven days). In our study $M$. parvifolia presented 16.1 $\pm 0.04 \mathrm{mg} \mathrm{GAE}^{-1} \mathrm{dw}$ by UAE (Shaker $=12.6 \pm$ $0.06 \mathrm{mg} \mathrm{GAE} \mathrm{g}^{-1} \mathrm{dw}$ ). To the best of our knowledge there are no reports about concentration of phenolic compounds in M. parvifolia.

Distinctively, UAE and orbital shaker methods yield average values of FPC very similar for shoots of grass $P$. vaginatum $(\mathrm{UAE}=12.0 \pm 0.34$ mg GAE g ${ }^{-1} \mathrm{dw}$; Shaker $=12.2 \pm 0.22 \mathrm{mg} \mathrm{GAE}$ $\left.\mathrm{g}^{-1} \mathrm{dw}\right)$, soybean $\left(\mathrm{UAE}=2.29 \pm 0.18 \mathrm{mg} \mathrm{GAE} \mathrm{g}^{-1}\right.$ $\mathrm{dw}$; Shaker $\left.=2.38 \pm 0.21 \mathrm{mg} \mathrm{GAE} \mathrm{g}^{-1} \mathrm{dw}\right)$ and rice bran $\left(\mathrm{UAE}=7.10 \pm 0.03 \mathrm{mg} \mathrm{GAE} \mathrm{g}^{-1} \mathrm{dw}\right.$; Shaker $\left.=7.02 \pm 0.33 \mathrm{mg} \mathrm{GAE} \mathrm{g}^{-1} \mathrm{dw}\right)(p>0.05$; see Figure 2). We believe that these three matrices were particularly rich in free phenols, reachable by both extraction methods. In the review of $P$. vaginatum, Lonard et al. (2015) pointed out that this grass is a true halophyte with enhanced growth at low salinity, and osmotic adjustments enhanced by the accumulation of potassium ions and the amino acid proline in its tissue. According to these authors there is no report available about bioactive compounds or medical uses of $P$. vaginatum, although many ecotypes of this species are resistant to insects that normally cause severe damage to lawns and other types of recreational sites in the coastal zone. Thus, this species is probably rich in chemical defense compounds, such as phenols. To our knowledge this work was the first to report FPC in $P$. vaginatum.

Although soybean and rice bran have high bound phenols concentrations, the industrial processing and storing of grains may release bound phenols (Scaglioni et al. 2014, Xiao et al. 2015). The significant phenolic content in soybean and rice bran (Scaglioni et al. 2014, Ali et al. 2015) is often associated to defense mechanisms against disease and pests (Nicholson and Hammerschmidt 1992). In soybeans, the content of phenolic compounds is responsible for the flavor (Alu'datt et al. 2013) and genetic modification may change the composition of the seed by increased defense mechanism where the phenolic compounds are included (Ladics et al. 2014). The soy cultivar used in our study was not genetically modified and showed intermediate FPC contents among values found by Alu'datt et al. (2013) (1.87 $\left.\mathrm{mg} \mathrm{g}^{-1}\right)$. In comparison with others published FPC contents in rice bran by different extraction methods (Scaglioni et al. 2014), our UAE and orbital shaker results ranked in the midupper range of obtained values.

\section{CONCLUSIONS}

In this work, ultrasound-assisted extraction (UAE) was optimized for $S$. ambigua shoots, although halophytes may present high concentration of interfering factors (e.g. $\mathrm{Na}^{+}, \mathrm{Cl}^{-}, \mathrm{K}^{+}$, metals, lignification, others) in the extraction and detection ofFPC. The experimental design tested was efficient to find the optimal conditions of the extraction. The proposed method proved to be accurate and precise, with recuperation percentages around 99.5 per cent and precision lower than 20 per cent of variation.

This work was the first to report FPC in $M$. parvifolia and $P$. vaginatum. All halophytes species showed to be good natural sources of FPC. The optimized UAE method proved to be a better 
extraction procedure than the orbital shaker method for $S$. ambigua and most of others halophyte matrices tested (A. graveolens, M. parvifolia and $S$. terenbithifolius). Furthermore, the optimized UAE method is faster than the orbital shaker method, providing shorter exposure of the analyst to the extractor solvent.

\section{ACKNOWLEDGMENTS}

This work was supported by the Conselho Nacional de Desenvolvimento Científico e Tecnológico (CNPq) (CSB Costa; grant number 573884/2008-0-INCTSAL and 408921/2013). The authors were sponsored by Coordenação de Aperfeiçoamento de Pessoal de Nível Superior (CAPES) (MM de Souza).

\section{REFERENCES}

ABID M, JABBAR S, WU T, HASHIM MM, HU B, LEI S AND ZENG X. 2014. Sonication enhances polyphenolic compounds, sugars, carotenoids and mineral elements of apple juice. Ultrason Sonochem 21: 93-97.

ALI NM, YEAP SK, YUSOF HM, BEH BK, HO WY, KOH SP, ABDULLAH MP, ALITHEEN NB AND LONG K. 2016. Comparison of free amino acids, antioxidants, soluble phenolic acids, cytotoxicity and immunomodulation of fermented mung bean and soybean. Sci Food Agri 96(5): 1648-1658.

ALU'DATT MH, RABABAH T, EREIFEJ K AND ALLI I. 2013. Distribution, antioxidant and characterisation of phenolic compounds in soybeans, flaxseed and olives. Food Chem 139: 93-99.

AOAC. 2002. Validation of chemical methods for dietary. Supplements and botanicals, Guidelines for single laboratory.

ARRUDA HS, PEREIRA GA AND PASTORE GM. 2017. Optimization of extraction parameters of total phenolics from Annona crassiflora Mart. (Araticum) fruits using response surface methodology. Food Anal Methods 10: 100-110.

BERTIN RL, GONZAGA LV, BORGES GDSC, AZEVEDO MS, MALTEZ HF, HELLER M, MICKE GA, TAVARES LBB AND FETT R. 2014. Nutrient composition and, identification/quantification of major phenolic compounds in Sarcocornia ambigua (Amaranthaceae) using HPLCESI-MS/MS. Food Res Int 55: 404-411.
BERTIN RL, MALTEZ HF, GOIS JS, BORGES DLG, BORGES GSC, GONZAGA LV AND FETT R. 2016. Mineral composition and bioaccessibility in Sarcocornia ambigua using ICP-MS. J Food Compos Anal 47: 45-51.

COSTA CSB ET AL. 2006. Effect of ultraviolet-B radiation on salt marsh vegetation: Trends of the genus Salicornia along the Americas. Photochem Photobiol 82: 878-886.

COSTA CSB AND HERRERA OB. 2016. Halophytic life in Brazilian salt flats: Biodiversity, uses and threats. In: Khan MA, Boër B, Ozturk M, Clüsener-Godt M, Gul B and Breckle SW (Eds), Sabkha Ecosystem V: The Americas. Springer International Publishing, Berlin, p. 11-27.

COSTA CSB, VICENTI JRM, MORÓN-VILLAREYES JA, CALDAS S, CARDOSO LV, FREITAS RF AND D'OCA MGM. 2014. Extraction and characterization of lipids from Sarcocornia ambigua meal: a halophyte biomass produced with shrimp farm effluent irrigation. An Acad Bras Cienc 86: 935-943.

DE SOUZA VR, PEREIRA PAP, DA SILVA TLT, DE OLIVEIRA LIMA LC, PIO R AND QUEIROZ F. 2014. Determination of the bioactive compounds, antioxidant activity and chemical composition of Brazilian blackberry, red raspberry, strawberry, blueberry and sweet cherry fruits. Food Chem 156: 362-368.

FLOWERS TJ AND COLMER TD. 2015. Plant salt tolerance: adaptations in halophytes. Ann Bot 115: 327-331.

GARCIA-SALAS P, MORALES-SOTO A, SEGURACARRETERO A AND FERNÁNDEZ-GUTIÉRREZ A. 2010. Phenolic-compound-extraction systems for fruit and vegetable samples. Molecules 15: 8813-8826.

GLENN EP, ANDAY T, CHATURVEDI R, MARTINEZGARCIA R, PEARLSTEIN S, SOLIZ D, NELSON SG AND FELGER RS. 2013. Three halophytes for salinewater agriculture: An oilseed, a forage and a grain crop. Environ Exp Bot 92: 110-121.

GONZÁLEZ-CENTENO MR, COMAS-SERRAF, FEMENIA A, ROSSELLÓ C AND SIMAL S. 2015. Effect of power ultrasound application on aqueous extraction of phenolic compounds and antioxidant capacity from grape pomace (Vitis vinifera L.): Experimental Kinetics and modeling. Ultrason Sonochem 22: 506-514.

JALLALI I, ZAOUALI Y, MISSAOUI I, SMEOUI A, ABDELLY C AND KSOURI R. 2014. Variability of antioxidant and antibacterial effects of essential oils and acetonic extracts of two edible halophytes: Crithmum maritimum L. and Inula crithmoïdes L. Food Chem 145 1031-1038.

JBIR N, CHAÏBI W, AMMAR S, JEMMALI A AND AYADI A. 2001. Root growth and lignification of two wheat species differing in their sensitivity to $\mathrm{NaCl}$, in response to salt stress. Comptes Rendus l'Académie des Sci - Ser. III - Sci la Vie 324: 863-868. 
KRISHNASWAMY K, ORSAT V, GARIÉPY Y AND THANGAVEL K. 2013. Optimization of MicrowaveAssisted Extraction of Phenolic Antioxidants from Grape Seeds (Vitis vinifera). Food Bioprocess Technol 6: 441455.

LADICS GS, BUDZISZEWSKI GJ, HERMAN RA, HEROUET-GUICHENEY C, JOSHI S, LIPSCOMB EA, MCCLAIN S AND WARD JM. 2014. Measurement of endogenous allergens in genetically modified soybeans - Short communication. Regul Toxicol Pharmacol 70: 7579.

LONARD RI, JUDD FW AND STALTER R. 2015. Biological flora of coastal dunes and wetlands: Paspalum vaginatum Sw. J Coast Res 31: 213-223.

LUTTS S AND LEFÈVRE I. 2015. How can we take advantage of halophyte properties to cope with heavy metal toxicity in salt-affected areas? Ann Bot 115: 509-528.

MISHRA A, PATEL MK AND JHA B. 2015. Non-targeted metabolomics and scavenging activity of reactive oxygen species reveal the potential of Salicornia brachiata as a functional food. J Funct Foods 13: 21-31.

NICHOLSON RL AND HAMMERSCHMIDT R. 1992. Phenolic compounds and their role in disease resistance. Annu Rev Phytopathol 30: 369-389.

RIBEIRO JNS AND COSTA CSB. 2015. The effect of temperature regulation on seed germination of the tropical tree Myrsine parvifolia A. DC near its southern limit. South African J Bot 98: 128-133.

ROZEMA J AND SCHAT H. 2013. Salt tolerance of halophytes, research questions reviewed in the perspective of saline agriculture. Environ Exp Bot 92: 83-95.

SANTOS HM, LODEIRO C AND CAPELO-MARTÍNEZ J-L. 2009. The Power of Ultrasound. In: Ultrasound in Chemistry. Wiley-VCH Verlag GmbH \& Co. KGaA, Weinheim, Germany, p. 1-16.

SCAGLIONI PT, DE SOUZA TD, SCHMIDT CG AND BADIALE-FURLONG E. 2014. Availability of free and bound phenolic compounds in rice after hydrothermal treatment. J Cereal Sci 60: 526-532.

SCHMIDTCG, GONÇALVES LM, PRIETTOL, HACKBART HS AND FURLONG EB. 2014. Antioxidant activity and enzyme inhibition of phenolic acids from fermented rice bran with fungus Rizhopus oryzae. Food Chem 146: 371377.

SINGLETON VL AND ROSSI JAJ. 1965. Colorimetry of total phenolics with phosphomolybdic-phossphotungstic acid reagents. Am J Enol Vitic 16: 144-158.

SLAMA I, ABDELLY C, BOUCHEREAU A, FLOWERS T AND SAVOUREA. 2015. Diversity, distribution and roles of osmoprotective compounds accumulated in halophytes under abiotic stress. Ann Bot 115: 433-447.

SOUZA MM DE, RECART VM, ROCHA M DA, CIPOLATTI EP AND BADIALE-FURLONG E. 2009. Study on the extracting conditions of phenolic compounds from onion (Allium cepa L.). Rev Inst Adolfo Lutz 68: 192-200.

STANKOVIĆ MS, PETROVIĆ M, GODJEVAC D AND STEVANOVIĆ ZD. 2015. Screening inland halophytes from the central balkan for their antioxidant activity in relation to total phenolic compounds and flavonoids: Are there any prospective medicinal plants? J Arid Environ 120: 26-32.

SUFFREDINI IB, PACIENCIA ML, VARELLA AD AND YOUNES RN. 2006. Antibacterial activity of Brazilian Amazon plant extracts. Brazilian J Infect Dis 10: 400-402.

TIMM TG, JÚNIOR AAS, BERTIN RL AND TAVARES LBB. 2015. Processamento de conservas de Sarcocornia perennis. Agropecu Catarin 28: 97-102.

UDDIN K, JURAIMI AS, ISMAIL MR, HOSSAIN A, OTHMAN R AND ABDUL RAHIM A. 2012. Physiological and growth responses of six turfgrass species relative to salinity tolerance. Sci World J 2012: Article ID 905468, 10 pages.

ULIANA MP, FRONZA M, DA SILVA AG, VARGAS TS, DE ANDRADE TU AND SCHERER R. 2016. Composition and biological activity of Brazilian rose pepper (Schinus terebinthifolius Raddi) leaves. Ind Crops Prod 83: 235240.

VENTURA Y, WUDDINEH WA, MYRZABAYEVA M, ALIKULOV Z, KHOZIN-GOLDBERG I, SHPIGEL M, SAMOCHA TM AND SAGI M. 2011. Effect of seawater concentration on the productivity and nutritional value of annual Salicornia and perennial Sarcocornia halophytes as leafy vegetable crops. Sci Hortic (Amsterdam) 128: 189196.

WANG X, CAI C AND LI X-M. 2016. Optimal Extraction of Gallic Acid from Suaeda glauca Bge. Leaves and Enhanced Efficiency by Ionic Liquids. Int J Chem Eng 2016: $1-9$.

WHEELER GS, MASSEY LM AND ENDRIES M. 2001. The Brazilian peppertree drupe feeder Megastigmus transvaalensis (Hymenoptera: Torymidae): Florida distribution and impact. Biol Control 22: 139-148.

XIAO Y, WANG L, RUI X, LI W, CHEN X, JIANG M AND DONG M. 2015. Enhancement of the antioxidant capacity of soy whey by fermentation with Lactobacillus plantarum B1-6. J Funct Foods 12: 33-44.

YAO Y, SANG W, ZHOU M AND REN G. 2010. Phenolic composition and antioxidant activities of 11 celery cultivars. J Food Sci 75: C9-C13. 